\title{
Research on the patterns of structure formation processes of a clinker-free alkaline stone
}

\author{
S-A.Yu. Murtazaev, M.Sh. Salamanova \& M.Sh. Mintsaev \\ FSFEI HE "Millionschikov Grozny State Oil Technical University”, Kh. Ibragimov Complex Institute of \\ the Russian Academy of Sciences, Grozny, Russia \\ D.K-S. Bataev \\ Kh. Ibragimov Complex Institute of the Russian Academy of Sciences, Grozny, Russia
}

\begin{abstract}
Resource- and energy-consuming Portland cement is currently considered the most popular material in construction, but its production is classified as harmful due to the large amount of emissions into the environment. Therefore, the development of a clinker-free technology for the production of binders based on mineral fine-dispersed powders of aluminosilicate nature, activated by an alkaline grouting fluid, is an urgent and promising direction.

The research presents the results of a study on the laws of processes occurring during the structure formation of clinker-free binder systems of alkaline activation on alkaline cements using blast furnace granulated slags in a finely dispersed state. Formulations are given and the properties of clinker-free binders of alkaline activation based on mineral finely dispersed powders from rocks of sedimentary and magmatic origin are investigated. Electron probe analysis and X-ray phase analysis revealed the presence of hydrated amorphous compounds close in composition to zeolites in cement stone. An analysis of the results allowed us to determine the optimal composition of clinker-free binder of alkaline activation "silicified marl + volcanic tuff $(70: 30 \%)+\mathrm{Na}_{2} \mathrm{SiO}_{3}+\mathrm{NaOH}$ " with activity ranging from $42.0-54.5 \mathrm{MPa}$, depending on the conditions under which the hardening of the samples was implemented.

This work was carried out as part of research on the implementation of scientific project No. 05.607.21.0320. "Development of technology for new building composites on clinkerless alkaline binders using substandard natural and secondary raw materials" that received support from the federal target program "Research and Development in Priority Directions for the Development of the Russian Science and Technology Complex for 2014-2020”. Unique Agreement Identifier RFMTFI60719X0320.
\end{abstract}

Keywords: High-strength concrete, super concrete, local raw materials, products of buildings and constructions demolition and dismantling, concrete scrap, brick rubble, recycling, secondary or recycled filler (sand), filled binder, concrete

\section{INTRODUCTION}

The fundamental factor in the formation of structure-forming elements, both of various dense rocks, and for all traditional mineral binders is the presence of an alkaline environment created by alkaline and alkaline earth metals. Minerals such as zeolites and feldspars in the $\mathrm{Na}_{2}$ $\mathrm{O}-\mathrm{Al}_{2} \mathrm{O}_{3}-\mathrm{SiO}_{2}-\mathrm{H}_{2} \mathrm{O}$ system were formed as a result of metamorphic processes in the earth's crust, under conditions of high temperatures, humidity, pressures, weathering and cementation with alkaline compounds of aluminosilicate rocks. But it must be taken into account that in alkaline cements, the main astringent function is performed by com-pounds of alkali metals with silicates, aluminates, and water, which are much more active than alkaline 
earth oxides and create a stronger alkaline environment (Glukhovsky et al., 1981, Glukhovsky et al., 1980).

The mechanism for creating durable compositions from traditional cements is based on the synthesis of calcium salts, which, when hydrated, give an alkaline environment saturated with calcium hydroxide, which will subsequently become a component of crystallization formations. Having located the elements of alkali-containing compounds in basicity: $\mathrm{Cs}, \mathrm{Kb}$, $\mathrm{K}, \mathrm{Na}, \mathrm{Li}, \mathrm{Ba}, \mathrm{Sr}, \mathrm{Ca}, \mathrm{Mg}$, we observe a decrease in activity and $\mathrm{pH}$ of the medium from left to right, therefore, caustic alkalis of sodium and potassium are strong bases, and will allow to obtain multicomponent cement systems with hydraulic properties (Glukhovsky et al., 1981, Krivenko et al., 1993, Salamanova \& Murtazaev et al., 2017, Murtazaev \& Salamanova et al., 2018).

\section{LITERATURE REVIEW}

A study of the issues related to the reactivity of the studied compounds showed that the minerals of alkaline-earth aluminosilicates, silicates, aluminates do not react with water, and for the hydration interaction to occur, it is necessary to increase the basicity of the dispersion phase, which is possible by introducing an alkaline component into the hardener, which will lead to the formation of a system with a clear increase in strength indicators.

In the works of Glukhovsky (Glukhovsky et al., 1981, Glukhovsky et al., 1980) it is proposed to classify the hydration characteristics of alkaline compounds depending on the chemical and mineralogical compositions:

- caustic alkali solutions of ROH type;

- soft acids salts of non-siliceous nature, such as $\mathrm{R}_{2} \mathrm{CO}_{3}, \mathrm{R}_{2} \mathrm{SO}_{3}, \mathrm{R}_{2} \mathrm{~S}$, RF, etc.;

- siliceous salt of the $\mathrm{R}_{2} \mathrm{O}-(0,5-4,0)-\mathrm{SiO}_{2}$ composition;

- aluminate salts of the $\mathrm{R}_{2} \mathrm{O}-\mathrm{Al}_{2} \mathrm{O}_{3}$ composition;

- aluminosilicate salts of the $\mathrm{R}_{2} \mathrm{O}-\mathrm{Al}_{2} \mathrm{O}_{3}-(2-6) \mathrm{SiO}_{2}$ type;

- salts of strong acids of non-siliceous nature such as $\mathrm{RCl}, \mathrm{R}_{2} \mathrm{SO}_{4}$.

The hydration ability was studied (Davidovitz et al., 2008, Duxson et al., 2007, Nikiforov et al., 2011, Krivenko et al., 2006) on samples of normal consistency, from blast furnace granulated slag of aluminosilicate nature, mixed with the corresponding alkaline solutions, with $\mathrm{Na}_{2} \mathrm{O}$ content in a binder (up to $3 \%$ ). Table 1 shows a comparative analysis of slag-alkali compositions.

The dependence of the strength index of the studied alkaline compositions on the type of alkaline solution showed that the activity of binders is determined by the nature of the grouting fluid, and reaches its highest index in compounds with alkali metals + silicates of high basicity (Rakhimova et al., 2009). Therefore, the strength indicators of alkaline systems depend on the degree of their solubility and dissociation in water.

Aluminosilicate alkaline groutings, as we know, do not dissolve in water, but as a result of interaction with it, they break off a weak concentration of caustic soda. Aluminates and sodium silicates are readily soluble in water and the results of studies (Murtazaev \& Salamanova et al., 2019) confirm their hydration hardening inherent in alkaline earth compounds. Consequently, the dispersed alkaline phase, necessary for hydration processes to form cement

Table 1. The results of determining the activity of blast surface slag compositions (slag compositions in short) (Glukhovsky et al., 1980).

Compressive strength, MPa

\begin{tabular}{lllllllllll}
\hline Water & $\mathrm{NaOH}$ & $\mathrm{Na}_{2} \mathrm{CO}_{3}$ & $\mathrm{NaNO}_{3}$ & $\mathrm{NaF}$ & $\mathrm{Na}_{2} \mathrm{~S}$ & $\mathrm{Na}_{2} \mathrm{SiO}_{3}$ & $\begin{array}{l}\mathrm{Na}_{2} \mathrm{O} \\
2 \mathrm{SiO}_{2}\end{array}$ & $\begin{array}{l}\mathrm{Na}_{2} \mathrm{O} \\
4 \mathrm{SiO}_{2}\end{array}$ & $\begin{array}{l}\mathrm{Na}_{2} \mathrm{O} \mathrm{Al}_{2} \mathrm{O}_{3} \\
2 \mathrm{SiO}_{2}\end{array}$ & $\begin{array}{l}\mathrm{Na}_{2} \mathrm{O} \\
\mathrm{Al}_{2} \mathrm{O}_{3}\end{array}$ \\
\hline 7,5 & 80 & 63 & 55 & 85 & 60 & 130 & 160 & 23 & 10 & 67 \\
\hline
\end{tabular}


stone, will be an indispensable condition, and the previously known (Glukhovsky et al., 1980, Duxson et al., 2007, Nikiforov et al., 2011, Krivenko et al., 2006, Bataev \& Salamanova et al., 2019) scientific, theoretical and experimental approaches to creating hydraulic binders based on calcium oxide will help to model the algorithm obtaining clinker-free bindings with mineral powders of alkaline mixing.

\section{RESEARCH METHODS AND MATERIALS}

The regularities and laws of the processes occurring during the formation of the structure of clinker-free binder systems of alkaline activation were studied on slag-alkali cements using blast furnace granulated slags in a finely dispersed state (Rakhimova et al., 2009, Davidovitz et al., 2008, Krivenko et al., 2006, Murtazayev \& Alaskhanov et al., 2019). It has been established that compounds of the Si-O-Si and Al-O-Si type in a solution of alkali metals of high concentration are first destroyed, but after a certain time they become denser, trans-forming into a colloidal state.

The mechanism of the structure formation process is quite long and complex. At the first stage of hardening, the dispersed slag particles spontaneously dissolve in the alkali metal solution with the formation of dispersion-coagulative solutions necessary for the formation of the initial structure. Primary neoplasms formed as a result of cationic ex-change of $2 \mathrm{Na}^{+} \leftrightarrow \mathrm{Ca}^{2+}$ are variable in nature.

At the next stage, the formed condensation structure transforms due to mass transfer processes in the colloidal dispersed system, and the transition of hydrosols to the solid phase, which intensifies the crystallization of the structure. A particular alkaline system was studied in a few research papers and it was represented by the following system " $\mathrm{Ca}(\mathrm{OH})_{2}-\mathrm{SiO}_{2}-\mathrm{H}_{2}$ $\mathrm{O}-\mathrm{NaOH}$ ", and so with the molar ratio $\mathrm{Ca}(\mathrm{OH})_{2} / \mathrm{SiO}_{2}=1$, the development of phase formation can be traced:

at $\mathrm{NaOH} / \mathrm{SiO}_{2}<1$, the tobermorite phase is $11.3 \AA$ with silicon-oxygen anions;

at $\mathrm{NaOH} / \mathrm{SiO}_{2}=1-5$, the tobermorite phase is $11.3 \AA$ with the chain structure of siliconoxygen anions;

at $\mathrm{NaOH} / \mathrm{SiO}_{2}>5$, sodium cation in the tobermorite phase is $\mathrm{NaCaHSiO}_{4}$ with $\mathrm{SiO}_{4}$ being isolated.

And at the last stage of structure formation, the primary solid phases of an unstable composition develop, leading to the formation of a strong crystalline intergrowth. The crystallization phases are unstable, and depend on many factors, chemical and mineralogical compositions that make up the system, the nature of the alkaline solution, the dispersion of the components, hardening conditions, etc. Alkaline medium of high basicity promotes the formation of compounds such as tobermorite like low basic calcium hydrosilicates CSH (B), variable hydrogranates, silicic acid gel, alkaline hydroaluminosilicates such as natural zeolites and hydromica, and other alkaline-alkaline earth compounds of variable composition (Rakhimova et al., 2009).

The process of forming the structure of multicomponent systems "mineral powder - alkaline activator" requires a careful analysis, since the characteristics of the binder, its nature, degree of dispersion, alkaline curing agent (alkaline grouting fluid), their dissolution rate, crystallization conditions, interfacial contact zone, and other factors as a whole affect hardening and a cement stone's strength gain. Undoubtedly, the material and quantitative compositions of the components of this complex system will have a direct impact on the process at all stages of structure formation (Rakhimova et al., 2009, Krivenko et al., 2006, Murtazayev \& Alaskhanov et al., 2019).

This paper presents its view on the development of clinker-free technology for producing building composites. Considering the fact that in many regions of our vast country there are no reserves of ferrous metallurgy wastes, and transportation of this valuable raw material over long distances is economically disadvantageous, our efforts were aimed at finding materials that mutually substitute (or fill place of) blast furnace granulated slags. And this is no coincidence, the slag of ferrous metallurgy in their chemical composition is identical to the composition of clinker minerals, therefore, the processes of structure formation of cement 
stone will be similar for both types of binder. Due to the lack of slag, we made attempts to obtain alkaline mixing binders using finely dispersed mineral powders of various origins.

It becomes possible since the North Caucasus has huge natural potential for the development of the cement industry. In mountainous regions, stocks of cement marls, lime-stones, gaize (silica clay), dolomites, large deposits of mortar and glass sands, coquinoid limestone, sandstone (malmrock), natural sand dunes of the Terskaya lowland are concentrated (Salamanova \& Murtazaev et al., 2017).

To develop clinker-free cements of alkaline activation, mineral finely dispersed powders were prepared from rocks of sedimentary and magmatic origin: silicified marl and volcanic tuff from the Kabardino-Balkarian Republic.

\section{RESULTS}

The energy-dispersive microanalysis of the powders studied using a Quanta 3D 200 i scanning electron microscope showed a significant difference in the chemical composition of the mineral additives:

$\square$ Volcanic tuff, $\%: \mathrm{MgO}=0,20 ; \mathrm{Al}_{2} \mathrm{O}_{3}=13,57 ; \mathrm{SiO}_{2}=73,67 ; \mathrm{K}_{2} \mathrm{O}=6,00 ; \mathrm{CaO}=1,79 ; \mathrm{Fe}_{2}$ $\mathrm{O}_{3}=1,52 ; \mathrm{TiO}_{2}=2,85 ;$ other $=0,40$.

$\square$ Silicified marl, \%: $\mathrm{MgO}=1,64 ; \mathrm{Al}_{2} \mathrm{O}_{3}=6,42 ; \mathrm{SiO}_{2}=28,6 ; \mathrm{K}_{2} \mathrm{O}=1,33 ; \mathrm{CaO}=16,90 ; \mathrm{Fe}_{2}$ $\mathrm{O}_{3}=1,08 ; \mathrm{TiO}_{2}=0,47 ; \mathrm{SO}_{3}=0,29 ;$ other $=43,2$.

To study the structure formation processes of cement stone made with clinker-free binders of alkaline activation (CFBAA), electron-probe studies were carried out using a VEGA II LMU scanning electron microscope of the INCA ENERGY 450/XT energy dispersive microanalysis system while X-ray phase analysis was performed on an ARLX'TRA diffractometer. For research, samples were obtained from finely dispersed silicified marl, thermally activated at a temperature of $700{ }^{\circ} \mathrm{C}$, with a specific surface area of $1150 \mathrm{~m}^{2} / \mathrm{kg}$ and a finely ground volcanic tuff with a specific surface area of $905 \mathrm{~m}^{2} / \mathrm{kg}$, which were mixed in a predetermined ratio and subsequently tempered with an alkaline solution of salable liquid sodium glass with a silicate module of 2,8 and a density of $1,42 \mathrm{~g} / \mathrm{cm}^{3}$. The prepared samples solidified on the first day under normal conditions at a temperature of $20 \pm 2{ }^{\circ} \mathrm{C}$, but after 2 days the samples were being placed into a chamber drier for 2 hours at a temperature of $50{ }^{\circ} \mathrm{C}$ every day for the next 28 days.

The studied sample of cement stone is characterized by a thin-crystalline non-uniformly crystalline structure (Figure $1 \mathrm{c}$ ) with rounded closed pores with a diameter of up to $0,5 \mathrm{~mm}$ (Figure $1 \mathrm{a}, \mathrm{b}$ ). A commonly dense aggregation of cement mass with particles of sand aggregate is presented.

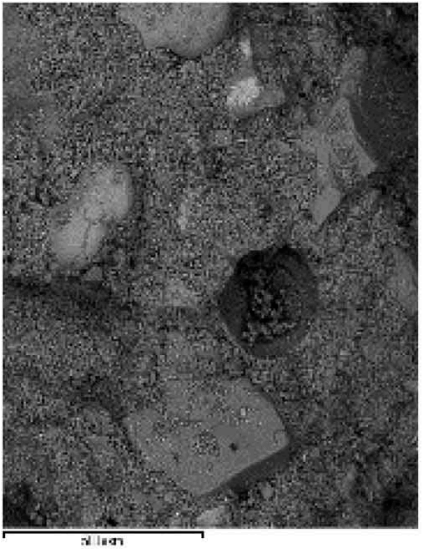

a)

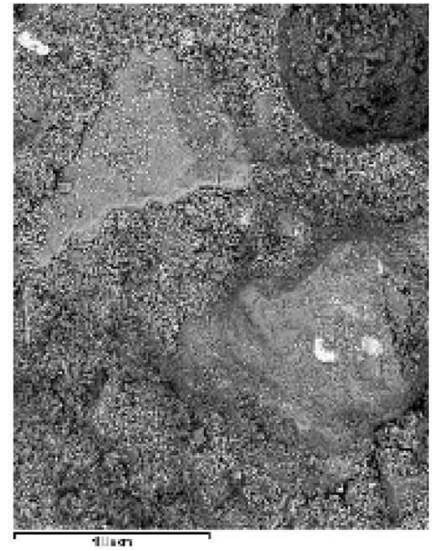

b)

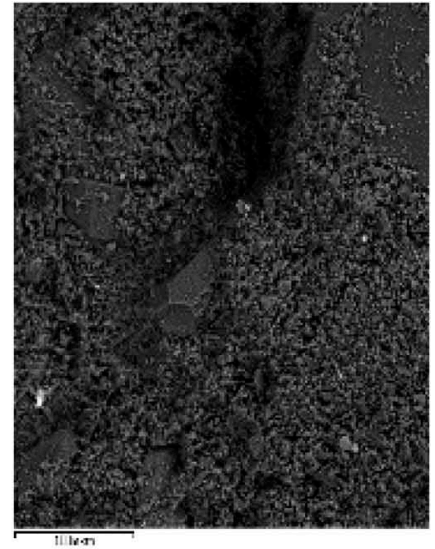

c)

Figure 1. The microstructure of CFBAA cement stone based on volcanic tuff and thermally activated marl. 


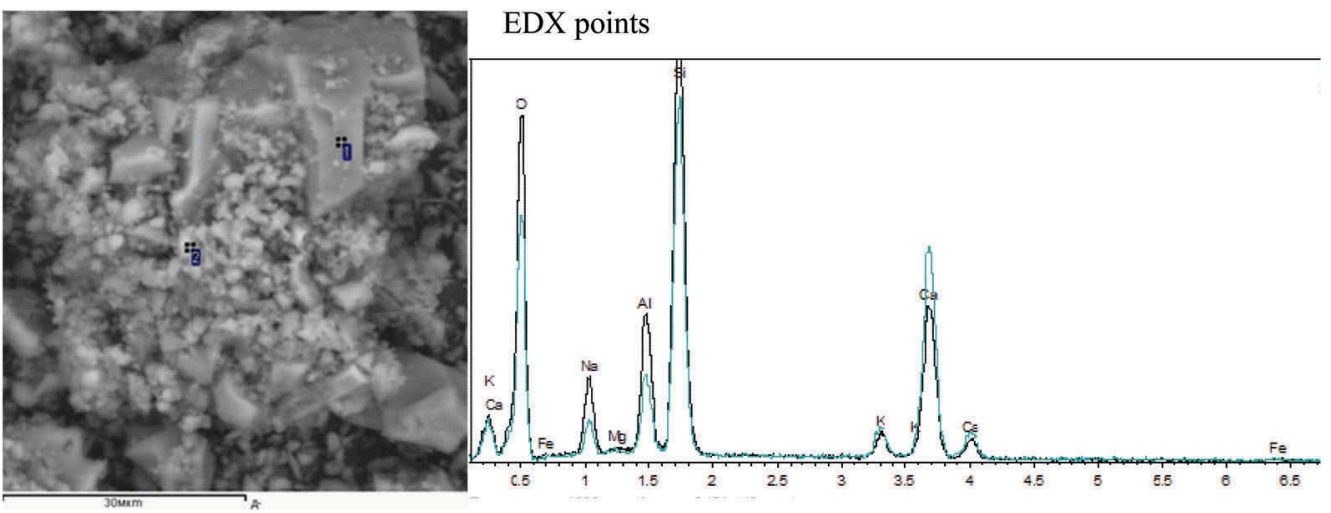

Figure 2. Hydrates of the fragments' mass $(1,2)$.

Table 2. The composition of the hydrates of the presented fragments' mass, in weight. \% (points [phases] of analysis are indicated in Figure 2).

\begin{tabular}{lllllllll}
\hline Point & $\mathrm{Na}_{2} \mathrm{O}$ & $\mathrm{MgO}$ & $\mathrm{Al}_{2} \mathrm{O}_{3}$ & $\mathrm{SiO}_{2}$ & $\mathrm{~K}_{2} \mathrm{O}$ & $\mathrm{CaO}$ & $\mathrm{FeO}$ & Total \\
\hline 1 & 8,19 & 0,22 & 12,51 & 46,98 & 2,05 & 17,71 & 0,43 & 88,09 \\
2 & 4,13 & 0,21 & 6,72 & 35,82 & 2,58 & 24,42 & 0,52 & 74,41 \\
\hline
\end{tabular}

Table 3. The composition of the crystals of the presented fractions' mass, in weight. \% (points [or phases] of analysis are indicated in Figure 3).

\begin{tabular}{lllrrrrrr}
\hline Point & $\mathrm{Na}_{2} \mathrm{O}$ & $\mathrm{MgO}$ & $\mathrm{Al}_{2} \mathrm{O}_{3}$ & $\mathrm{SiO}_{2}$ & $\mathrm{~K}_{2} \mathrm{O}$ & $\mathrm{CaO}$ & $\mathrm{FeO}$ & Total \\
\hline 1 & 8,66 & 0,00 & 18,76 & 61,65 & 1,66 & 7,61 & 0,40 & 98,74 \\
2 & 4,24 & 0,23 & 12,12 & 71,43 & 5,03 & 5,57 & 0,28 & 98,91 \\
3 & 0,92 & 0,21 & 1,14 & 5,98 & 0,23 & 44,52 & 0,00 & 53,00 \\
4 & 2,36 & 0,54 & 1,25 & 4,35 & 0,27 & 43,17 & 0,00 & 57,44 \\
5 & 0,74 & 0,00 & 1,03 & 4,06 & 0,33 & 42,55 & 0,00 & 48,70 \\
\hline
\end{tabular}

The main structure-forming layers are hydrates of sodium calcium aluminum silicates, often forming dense intergrowths of crystals up to 10-20 $\mu \mathrm{m}$ in size (Figure 2), the composition of which according to the results of a semi-quantitative analysis is shown in Tables 2, 3 (analyzes 1,2), which are associated with calcite and, apparently, thin layers of $\mathrm{Ca}(\mathrm{OH})_{2}($ Table 3, analyzes 3-5), as well as thin mica flakes.

Minerals of mica according to x-ray phase and electron probe analyzes correspond to muscovite; the measured flake composition $(\sim 20 \mu \mathrm{m}$ in size $)$ is on average close to the formula $\left(\mathrm{Na}_{0.14} \mathrm{~K}_{0.63}\right)_{0.8}\left(\mathrm{Fe}^{2+}{ }_{0.05} \mathrm{Mg}_{0.02} \mathrm{Al}^{\mathrm{VI}}{ }_{2.01} \mathrm{Ti}_{0.01}\right)_{2.1}\left(\mathrm{Si}_{3.01} \mathrm{Al}^{\mathrm{IV}}{ }_{0.99}\right)_{4.0} \mathrm{O}_{10}\left(\mathrm{OH}_{2.00}\right)_{2.0}$ reflecting the enrichment of sodium and aluminum.

According to the results of X-ray phase analysis, the presence of quartz, feldspars close to albite and orthoclase, mica, calcite, zeolites (Figure 4) was established.

\section{DISCUSSION}

According to $\mathrm{X}$-ray diffraction data, zeolite is identified as close to garronite. $\mathrm{Na}_{2} \mathrm{Ca}_{5} \mathrm{Al}_{12} \mathrm{Si}_{20}$ $\mathrm{O}_{64} \cdot 27\left(\mathrm{H}_{2} \mathrm{O}\right)$ distinctly expressed main reflex at this point (phase) $(2 \Theta-12,4(7,10 \AA))$. Electron probe studies reveal the presence of $\mathrm{Na}-\mathrm{Ca}-\mathrm{Si}$ hydrated amorphous compounds with a high 

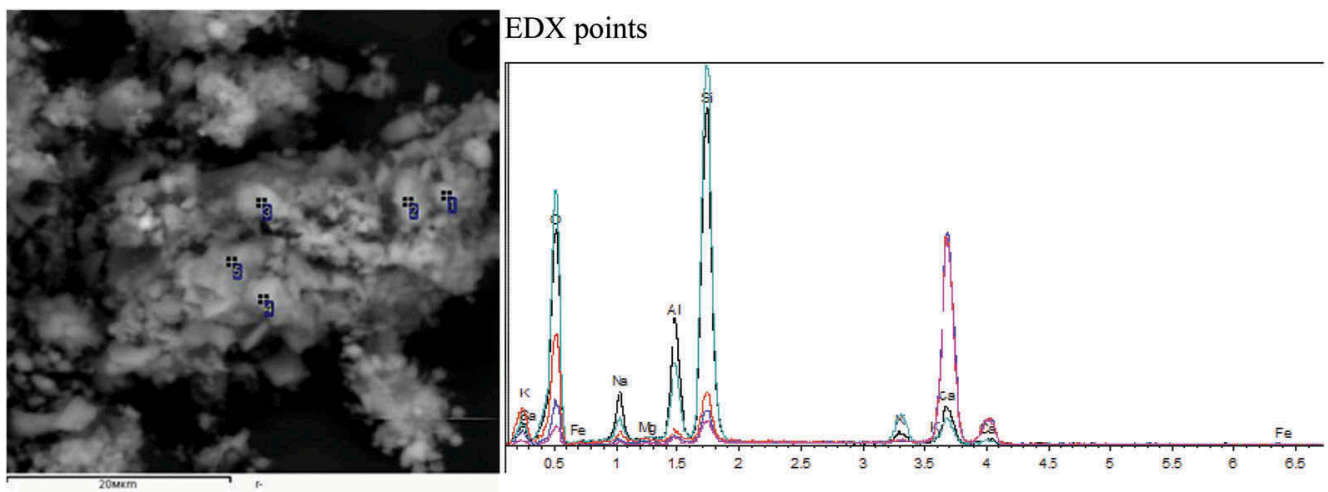

Figure 3. Points of the fragments' mass.

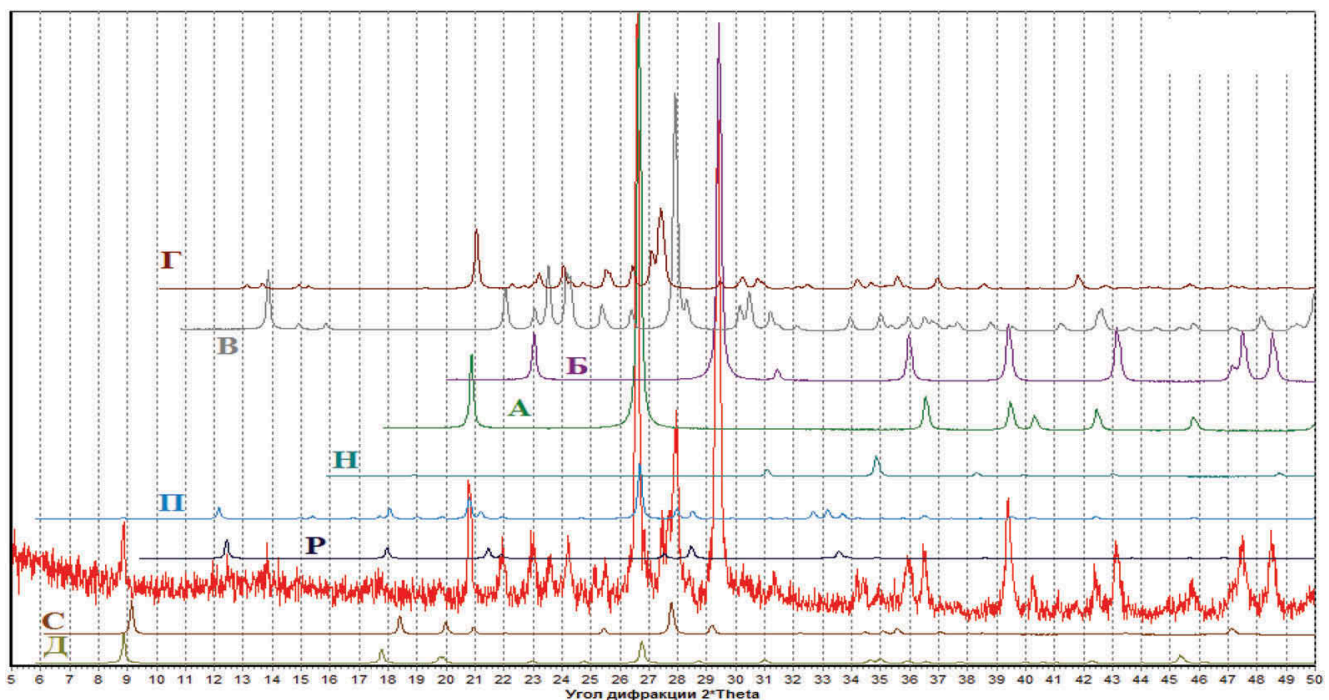

Figure 4. X-ray diffraction pattern of sample 1 in comparison with the data base PDF-2. The comparison points (phases) are as follows (the bracketed letters are Cyrillic Alphabet letters from Figure 4): A (A) - quartz, B (Б) - calcite, C (B) - albite, G (Г) - potassium feldspar, D (Д) - muscovite, $\mathrm{N}(\mathrm{H})$ - analcime, $\mathrm{P}(\Pi)$ - jismondite, $\mathrm{R}(\mathrm{P})$ - garronite, $\mathrm{S}(\mathrm{C})$ - paragonite.

water content (Figure 5, Table 4) and points (phases) similar to them in composition and also containing aluminum. Additionally, these points (phases) are similar to zeolites in elemental composition (Figure 6; 7, Tables 6 and 7).

The size and surface roughness of the preparations do not allow measurements by quantitative methods, but it can be stated that the composition is close to Ca-phillipsite or garronite (which are characterized by the ratio $-\mathrm{SiO}_{2} / \mathrm{Al}_{2} \mathrm{O}_{3} \sim 2$ ).

According to the results of X-ray phase analysis in a cement stone of the multicomponent system "mineral powder - alkaline activator" using finely dispersed volcanic tuff powders and thermally activated marl at $700{ }^{\circ} \mathrm{C}$, the presence of quartz, feldspars close to albite and orthoclase, mica, calcite, zeolites has been established. Electron probe studies also reveal the presence of hydrated amorphous Na-Ca-Si compounds of similar compositional phases containing aluminum and close in elemental composition to zeolites. 


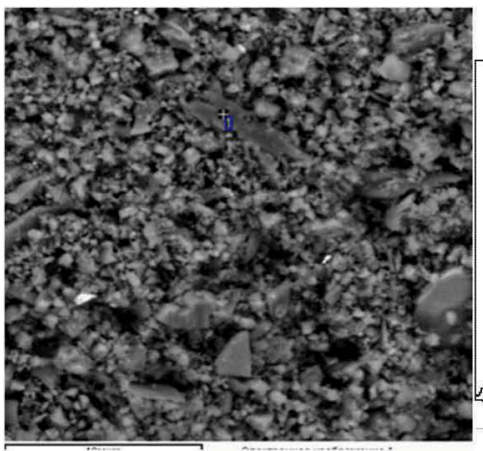

Figure 5. Hydrated Na-Ca-Si compounds in the structure of the material.

Table 4. The composition of the mica crystals, in weight. $\%$.

\begin{tabular}{llllllllll}
\hline Point & $\mathrm{Na}_{2} \mathrm{O}$ & $\mathrm{MgO}$ & $\mathrm{Al}_{2} \mathrm{O}_{3}$ & $\mathrm{SiO}_{2}$ & $\mathrm{~K}_{2} \mathrm{O}$ & $\mathrm{CaO}$ & $\mathrm{TiO}_{2}$ & $\mathrm{FeO}$ & Total \\
\hline 1 & 1,08 & 0,53 & 37,45 & 44,22 & 8,19 & 1,00 & 0,21 & 1,13 & 77,58 \\
\hline
\end{tabular}

Table 5. Composition of hydrated Na-Ca-Si compounds (points [or phases] of analysis are indicated in Figure 6), in weight. \%.

\begin{tabular}{lllllllll}
\hline Point & $\mathrm{Na}_{2} \mathrm{O}$ & $\mathrm{MgO}$ & $\mathrm{Al}_{2} \mathrm{O}_{3}$ & $\mathrm{SiO}_{2}$ & $\mathrm{~K}_{2} \mathrm{O}$ & $\mathrm{CaO}$ & $\mathrm{FeO}$ & Total \\
\hline 1 & 13,52 & 0,04 & 1,43 & 11,80 & 0,55 & 12,31 & 0,72 & 40,36 \\
\hline
\end{tabular}

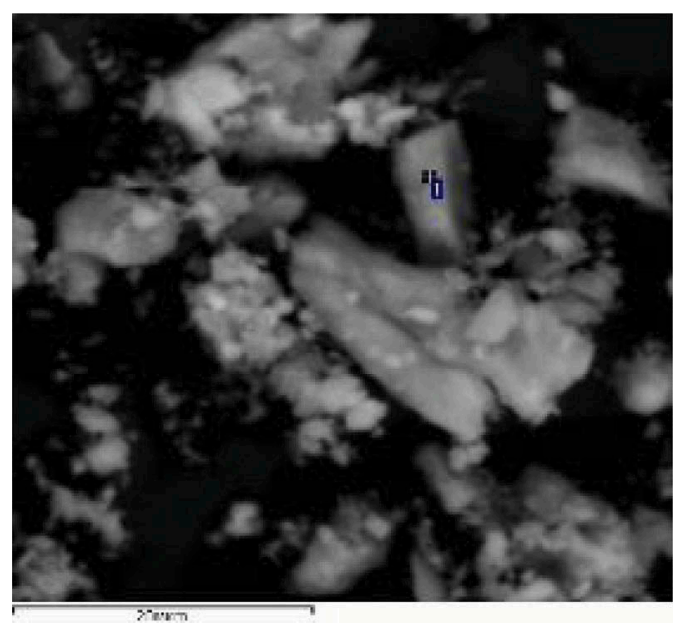

Figure 6. Hydrated Na-Ca-Si compounds in the structure of the material.

To study the kinetics of strength development of the clinker-free binder of alkaline activation, various compositions were prepared from finely dispersed silica marl thermally activated at a temperature of $700{ }^{\circ} \mathrm{C}$ with a specific surface of $1150 \mathrm{~m}^{2} / \mathrm{kg}$ and finely ground volcanic tuff with a specific surface of $905 \mathrm{~m}^{2} / \mathrm{kg}$, activated with an alkaline solution; the test results are given in Table 7. 

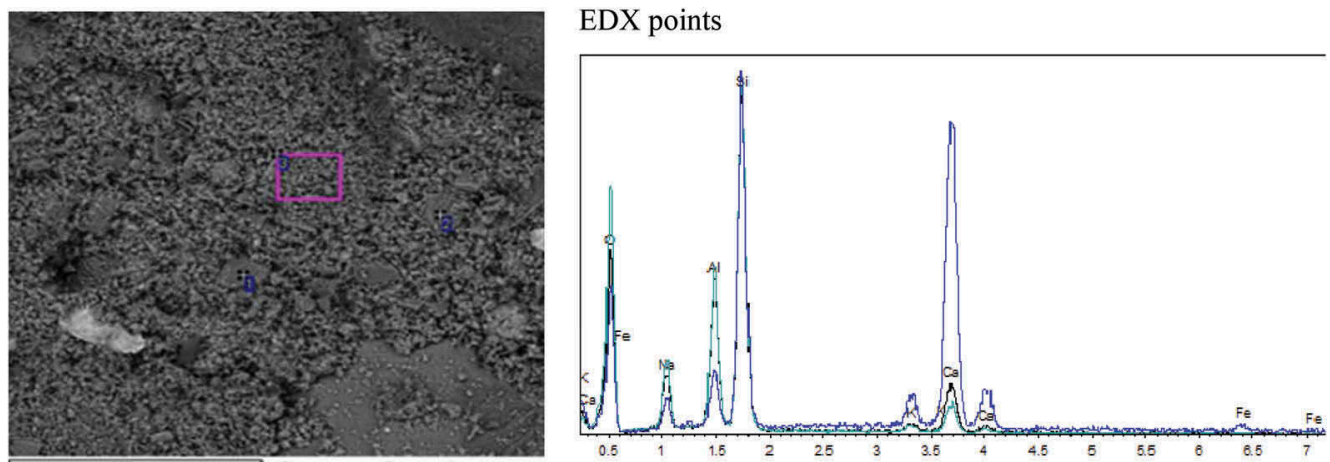

Figure 7. Points of EDX crystals close to zeolites $(1,2)$ и fragments' main mass (3).

Table 6. The composition of the zeolite point (phase) (points [or phases] of analysis are indicated in Figure 7), in weight. \%.

\begin{tabular}{llllllll}
\hline Point & $\mathrm{Na}_{2} \mathrm{O}$ & $\mathrm{Al}_{2} \mathrm{O}_{3}$ & $\mathrm{SiO}_{2}$ & $\mathrm{~K}_{2} \mathrm{O}$ & $\mathrm{CaO}$ & $\mathrm{FeO}$ & Total \\
\hline 1 & 5,12 & 17,07 & 40,91 & 0,39 & 6,47 & 0,13 & 71,09 \\
\hline
\end{tabular}

Table 7. Kinetics of strength development of the alkaline activation binder.

\begin{tabular}{|c|c|c|c|c|c|c|c|c|c|}
\hline \multirow[b]{3}{*}{ Alkaline activator } & \multicolumn{9}{|c|}{ The compressive strength, MPa per day } \\
\hline & \multicolumn{3}{|c|}{ after thermal treatment } & \multicolumn{3}{|c|}{ in water } & \multicolumn{3}{|c|}{ normal conditions } \\
\hline & 28 & 90 & 180 & 28 & 90 & 180 & 28 & 90 & 180 \\
\hline \multicolumn{10}{|c|}{$\underline{\text { silicified marl + volcanic tuff }(30: 70 \%)}$} \\
\hline $\mathrm{Na}_{2} \mathrm{SiO}_{3}+\mathrm{NaOH}$ & 24,5 & 25,1 & 26,0 & 18,3 & 23,4 & 24,5 & 18,3 & 18,4 & 19,5 \\
\hline $\mathrm{Na}_{2} \mathrm{SiO}_{3}$ & 20,1 & 20,5 & 22,3 & 16,5 & 17,3 & 18,5 & 16,6 & 17,2 & 17,6 \\
\hline $\mathrm{NaOH}$ & 15,0 & 15,1 & 15,3 & 12,4 & 13,3 & 13,4 & 12,2 & 13,0 & 13,3 \\
\hline \multicolumn{10}{|c|}{ silicified marl + volcanic tuff $(50: 50 \%)$} \\
\hline $\mathrm{Na}_{2} \mathrm{SiO}_{3}+\mathrm{NaOH}$ & 43,0 & 47,5 & 49,7 & 41,8 & 43,8 & 44,7 & 38,0 & 41,8 & 42,7 \\
\hline $\mathrm{Na}_{2} \mathrm{SiO}_{3}$ & 34,3 & 35,8 & 36,9 & 30,2 & 31,4 & 32,7 & 31,5 & 32,3 & 33,6 \\
\hline $\mathrm{NaOH}$ & 25,2 & 27,8 & 28,6 & 24,8 & 26,1 & 27,6 & 27,5 & 27,4 & 27,9 \\
\hline \multicolumn{10}{|c|}{ silicified marl + volcanic tuff $(70: 30 \%)$} \\
\hline $\mathrm{Na}_{2} \mathrm{SiO}_{3}+\mathrm{NaOH}$ & 46,5 & 52,4 & 54,5 & 45,6 & 47,6 & 49,6 & 42,0 & 43,7 & 44,3 \\
\hline $\mathrm{Na}_{2} \mathrm{SiO}_{3}$ & 37,2 & 38,6 & 40,8 & 35,4 & 38,4 & 39,9 & 34,1 & 36,3 & 37,5 \\
\hline $\mathrm{NaOH}$ & 30,0 & 31,6 & 32,7 & 30,4 & 31,2 & 33,1 & 28,7 & 28,8 & 30,9 \\
\hline
\end{tabular}

\section{CONCLUSIONS}

The results showed that clinker-free binder of alkaline activation of the "silicified marl + volcanic tuff $(70: 30 \%)-\mathrm{Na}_{2} \mathrm{SiO}_{3}+\mathrm{NaOH}$ " composition can be considered as an optimal one. The activity of cement stone varies from 42.0 to $54.5 \mathrm{MPa}$ depending on hardening conditions affecting the samples. It can be noted that heat treatment favorably affects the kinetics of the strength development of cement stone. Activation of the investigated multi-component systems with sodium hydroxide solution is inferior to sodium metasilicate. 
Thus, the obtained research results will significantly expand the scope of application of clinker-free cements of alkaline activation in regions experiencing a shortage of ferrous metallurgy waste, and become an alternative to energy and resource-consuming Portland cement, and, of course, it will be possible, if necessary, to replace it in the construction industry as the studies have confirmed the presence of hydrated amorphous Na-Ca-Si compounds, similar in composition of studied fragments' masses to zeolites, capable of facilitating the production of effective modern concrete composites.

\section{REFERENCES}

Bataev D.K-S., Murtazayev S- A. Yu., Salamanova M.Sh., Viskhanov S.S. 2019. Utilization of Cement Kiln Dust in Production of Alkali-Activated Clinker-Free Binders/Proceedings of the International Symposium "Engineering and Earth Sciences: Applied and Fundamental Research" dedicated to the 85th anniversary of H.I. Ibragimov (ISEES 2019). Atlantis Highlights in Material Sciences and Technology (AHMST). April 2019. Vol.1.

Davidovitz, J. 2008. Geopolymer. Chemistry and applications. Saint-Quentin: Institute Geopolymer.

Duxson, P. 2007. Geopolymer technology: The current state of the art//P. Duxson, A. Fernandez, J. Provis/J. Mater. Sci. - V. 42.

Glukhovsky, V.D. Slag-alkali concrete on fine-grained aggregates [Text]/V.D. Glukhovsky//Kiev: Vishcha school. Head Publishing House, 1981.- 224 p.

Glukhovsky, V.D. 1980. Complex use of blast furnace and electrothermophosphoric slag in the production of high-strength cements and concrete/ V.D. Glukhovsky, I.A. Pashkov, B.C. Grigoryev / University News: Construction and Architecture, - No. 5.

Krivenko, P.V. 1993. The durability of slag-alkali concrete/P.V. Krivenko, K.K. Pushkareva//- Kiev: Budivelnik.

Krivenko, P.V. 2006. Physicochemical fundamentals of the durability of slag stone/P.V. Krivenko// Cement. - 1990. - No. 11. - S. 2-4.10. Lecomte, I. Microstructural comparison between geopolymers, alkali-activated slag cement and Portland cement/I. Lecomte, C. Henrist, M. Liegeois//J. Eur. Cer. Soc. -2006 . - Vol. 26.

Murtazaev, S-A.Yu. 2017. The effect of surface active sites on the reactivity of mineral additives/S-A.Yu. Murtazaev, M.Sh. Salamanova, M.S. Saidumov, Z.Kh. Ismailova//Scientific journal "Modern Science and Innovation" (Stavropol - Pyatigorsk). - 2017. - No. 2 (18).

Murtazaev, S-A.Yu. 2018. Prospects for the use of thermally activated raw materials of aluminosilicate nature/C-A.Ю. Murtazaev, M.Sh. Salamanova//Volga Scientific Journal. - 2018. - No. 2 (T.46).

Murtazayev S- A. Yu., Salamanova M.Sh., Alaskhanov A.Kh, Ismailova Z.Kh 2019. Development of Multicomponent Binders Using Fine Powders/Proceedings of the International Symposium "Engineering and Earth Sciences: Applied and Fundamental Research" dedicated to the 85th anniversary of H.I. Ibragimov (ISEES 2019). Atlantis Highlights in Material Sciences and Technology (AHMST). April 2019. Vol.1.

Nikiforov, E.A. 2011. The effect of alkaline activation on the structure and properties of diatomite/E.A. Nikiforov, V.I. Loganina, E.E. Simonov//Bulletin of BSTU named after V.G. Shukhov. 2011. - No. 2.

Rakhimova, N.R. 2009. Properties of the slag-alkaline bindings - specific surface and granulometric of ground blast furnace slags relation/N.R. Rakhimova, R.Z. Rakhimov//17. Internationale Baustofftagung, Tagungsbericht. Band 1.Weimar.

Salamanova, M.Sh. 2019. Obtaining liquid glass silicate-sodium alkaline solutions from silica-containing additives/M.Sh. Salamanova, St. A.Yu. Murtazaev//Scientific and technical journal Vestnik GGNTU. Technical science. - 2019 .- No. 1(15). 